FACTA UNIVERSITATIS

Series: Economics and Organization Vol. 18, No 3, 2021, pp. 217 - 228

https://doi.org/10.22190/FUEO210628015A

Original Scientific Paper

\title{
THE DYNAMIC CAUSAL RELATIONSHIP BETWEEN OIL PRICE AND ECONOMIC GROWTH IN OIL-IMPORTING SSA COUNTRIES: A MULTIVARIATE MODEL
}

\author{
UDC 622.323:338.5]:330.34
}

\author{
Motunrayo O. Akinsola, Nicholas M. Odhiambo \\ University of South Africa, Department of Economics, Pretoria, South Africa \\ ORCID iD: Motunrayo O. Akinsola $\quad$ (ib) https://orcid.org/0000-0002-9822-2888 \\ Nicholas M. Odhiambo (ib) https://orcid.org/0000-0003-4988-0259
}

\begin{abstract}
This study examines the causal relationship between oil price and economic growth in 14 oil-importing countries in sub-Saharan Africa during the period 1990 to 2018. The countries are further divided into two groups, namely seven low-income countries (LICs) and seven middle-income countries (MICs) in order to test whether the causality between oil price and economic growth depends on the countries' income levels. Unlike previous studies that used a bivariate model, this study employs a multivariate Granger-causality model, which incorporates oil consumption and real exchange rate as intermittent variables in a bivariate setting between oil price and economic growth. The study employs panel cointegration and the panel Granger-causality tests to examine this linkage. The results of the study show that in the short run, there is a bidirectional causality between oil price and economic growth for the entire dataset, and both for the LICs and MICs. However, in the long run, there is a bidirectional causal relationship between oil price and economic growth for the entire dataset and MICs, but a unidirectional causality from economic growth to oil price for the LICs. Overall, the study found a feedback relationship between oil price and economic growth to be predominant.
\end{abstract}

Key words: oil price, economic growth, panel analysis, Granger causality, low-income countries, middle-income countries

JEL Classification: Q43; O55; C33

Received June 28, 2021 / Revised September 08 / Accepted September 14, 2021

Corresponding author: Motunrayo Akinsola

University of South Africa, Department of Economics, P.O Box 392, UNISA 0003, Pretoria, South Africa

| E-mail: tunrayo_sokoya@yahoo.com

(๑) 2021 by University of Niš, Serbia | Creative Commons Licence: CC BY-NC-ND 


\section{INTRODUCTION}

Research on the cause of oil price shocks has developed away from the traditional exogenous political disruptions in Organization of the Petroleum Exporting Countries (OPEC) member countries. Since the early 1980s, research has shown that oil price shocks from 1973 have mainly been due to shifts in the demand for crude oil, especially shifts in the global business cycle (Baumeister and Peersman, 2013; Kilian and Murphy, 2014; Baumeister and Kilian, 2016a; Baumeister and Kilian, 2016b). Baumeister and Kilian (2016a) highlight two determinants for the price of oil. First, an increase in global economic activities raises the demand for production input of oil, in particular, thereby raising the price of oil. Secondly, a speculative demand for oil might arise against future shortages in the oil market. The speculative demand for oil puts upward pressure on the expected price of oil. A persistent increase in the price of international crude oil puts upward pressure on domestic prices. The foreign exchange reserves are also affected through the exchange rate channel and make the oil-importing Sub-Saharan African (SSA) countries highly vulnerable to oil price shocks. The complete reliance of SSA countries on imported oil increases its vulnerability. The share of oil in the total energy mix for SSA countries is energy-dependent. Energy generation from coal is becoming popular beyond South Africa, but oil is still the largest in the energy mix of SSA countries. The demand for oil in SSA countries is estimated to be 1.8 million barrels per day. South Africa accounts for the highest oil demand in Africa with approximately $30 \%$ of the total demand for Africa. Nigeria accounts for more than $20 \%$ (OECD/IEA, 2014). Other countries in the region collectively consume the remaining half.

The literature confirms that there is a relationship between oil price and economic growth (Narayan et al., 2008; Du \& Wei, 2010; Aliyu, 2011; Romer, 2018; Sarwar et al., 2017). The existence of cointegration among the variables confirms the presence of a causal relationship among them in at least one direction; however, it does not explicitly state the direction of this causal relationship (Engle and Granger, 1987; Shahbaz et al., 2017). Moreover, findings on the causal relationship are mixed. In addition, some of the studies tend to suffer from omission-of-variable biases because they are based on bivariate analysis. Moreover, studies using panel data analysis for SSA countries are scanty. This study, therefore, uses a multivariate analysis to examine the causal relationship between oil price and economic growth in SSA countries during the period 1990 to 2018. The study further divides SSA countries into two groups, namely seven low-income countries (LICs) and seven middle-income countries (MICs) ${ }^{2}$ in order to test whether the causality between oil price and economic growth depends on the countries' income levels. The study employs panel cointegration and panel ECM-based Granger-causality tests to examine this linkage. To our knowledge, this study may be the first of its kind to examine in detail the causal relationship between oil price and economic growth in oil-importing countries in subSaharan Africa, using a multivariate panel Granger-causality model.

The rest of this paper is organised as follows: Section 2 gives a summary of previous studies on the relationship between oil price and economic growth; Section 3 presents the estimation techniques, empirical analysis and the discussion of the results, while Section 4 concludes the paper.

\footnotetext{
${ }^{2}$ The LICs include Ethiopia, Gambia, Mali, Mozambique, Senegal, Tanzania and Uganda. The MICs include Botswana, Kenya, Mauritania, Mauritius, Namibia, South Africa and Zambia.
} 


\section{LITERATURE REVIEW}

The causality between oil price and economic growth has been empirically tested in some studies as well, though the results are far from being consistent. Studies on the causal relationship between oil price and economic growth can be divided into four categories. The first category found Granger-causality flow from oil prices to economic growth. The second category found the Granger-causal relationship flow is from economic growth to oil prices. The third category of studies found the flow to be feedback hypothesis (two-way causal relationship) while the fourth category is the neutrality hypothesis (where there is no causal relationship). While most studies that exist have been conducted on developed countries, particularly the US, most studies on developing countries have been in Asia and Latin America. Little attention has been given to SSA countries that are usually mostly hit by oil price shocks.

Studies on oil prices and economic growth are few in comparison to studies on energy consumption and economic growth. Few studies have examined the nexus between oil prices and economic growth. Some of the studies that have examined oil price and economic growth include Hooker (1996a), Lescaroux and Mignon (2008), Cunado and Perez-de-Gracia (2003), Rafiq et al. (2009) and Kumar (2009). While some studies found a unidirectional causal relationship, other studies found the feedback hypothesis. Some studies also found mixed results for studies conducted in more than one country. There is, therefore, either causality or no causality in some of the countries employed in the study and under different data periods.

The consensus in the literature shows that oil and its price is pivotal in the economic activities of the world. Similarly, the magnitude and direction of its causal relationship are widely still debated in the literature. Assessing the consequences of oil price fluctuation on economic growth is specifically relevant to the case of oil-importing countries in SSA. As most of the oil-importing countries are small open economies and they have no real power on the global price of oil, hence they are greatly influenced by the effect of oil price variation especially as an importer of refined oil.

On the one hand, some studies found a unidirectional causal relationship between oil price and GDP. These include Rafiq et al. (2009); Kumar (2009) and Odhiambo and Nyasha (2019). Rafiq et al. (2009) analyzed data from Thailand and found that oil price does Granger cause and have a significant impact on macroeconomic indicators in the country. Kumar (2009) confirmed similar results for India using linear and nonlinear specifications of multivariate VAR. Evidence showed that oil price does Granger cause macroeconomic activities. A one percent decrease in the growth of industrial production is attributed to a one hundred percent increase in the oil price. Another study that found a unidirectional causality is Jayaraman and Choong (2009) in an analysis of four selected Pacific Island countries. They found that the causality runs from oil price to economic growth. Odhiambo and Nyasha (2019) also found a unidirectional causal relationship between oil price and economic growth in Kenya. The causal relationship, however, flows from economic growth to oil prices. Other studies on African countries that found a unidirectional causality between oil price and economic growth include Mensah et al. (2019) for a panel of 22 African countries and Awunyo-Victor et al. (2018) for Ghana.

On the other hand, a bidirectional causal relationship was found between oil price and economic growth in studies such as Sarwar et al. (2017); Shahbaz et al. (2017); JiménezRodríguez and Sánchez (2005); and Ebohon (1996). In a panel analysis of 157 countries, Sarwar et al. (2017) confirmed a bidirectional causal relationship in a multivariate analysis between oil price, GDP, electricity consumption, fixed capital formation and population. Shahbaz et al. (2017) found a similar result in a multivariate analysis of oil price, GDP and electricity 
consumption in a panel of 157 countries. In another study for eight OECD countries, JiménezRodríguez and Sánchez (2005) found a bi-directional relationship for five of the countries, namely: Japan, Canada, Germany, UK, and France. However, a unidirectional relationship (oil price Granger causes GDP) is found for the USA, Italy, and Norway. Ebohon (1996) also found a bidirectional relationship between energy and economic growth for both Nigeria and Tanzania.

Other studies found mixed results in their analysis. Hooker (1996a) found that oil price does not Granger-cause industrial production for the US using the VAR methodology from 1947 to 1994; however, oil price Granger causes unemployment and employment growth rates for data from 1947 to 1973 but not after 1973. Hooker (1996b) also found that oil price does not Granger-cause GDP for the US. Cunado and Perez-de-Gracia (2005) analyzed six Asian countries using VAR and quarterly data from 1975 to 2002. They found that oil price does not Granger-cause economic growth for half of the countries in the shortrun but does granger cause economic growth in South Korea, Japan, and Thailand. Lescaroux and Mignon (2008) examined three panel groups of oil-importing, oil-exporting and OPEC countries, and posited that oil price Granger-causes GDP for the oil importers and OPEC countries. However, they do not Granger-cause GDP for other oil exporters. Cunado and Perez-de-Gracia (2003) analysed 14 European countries using quarterly data from 1960 to 1999, and a VAR technique. They observed that oil prices Granger-cause GDP for half of the countries, but do not Granger-cause GDP for the other half.

\section{ESTIMATION TECHNIQUES AND EMPIRICAL ANALYSIS}

\subsection{Empirical Model Specification}

The Granger-causality test as proposed by Engle and Granger $(1987 ; 2004)$ is extended to examine the causal relationship between oil price, economic growth and oil consumption in a panel of 14 countries. Given the flaws of the bivariate causality framework (Dumitrescu and Hurlin, 2012), the current study uses a multivariate causality test to examine this linkage. According to Behmiri and Manso (2013), the omission of a vital variable in the causal link between two variables could result in omitted variable bias. To address this shortfall, a multivariate causality model is used to examine the causal relationship between real oil price (ROP) and economic growth (y). Oil consumption (OC) and real effective exchange rate (REER) are used as the intermittent variables in the multivariate models. The variables are expressed in their logarithm form. The model used in this study can be expressed as follows:

$$
\begin{aligned}
& \Delta y_{i t}=\propto_{1 j}+\sum_{k=1}^{n} \partial_{11 i k} \Delta y_{i t-k}+\sum_{k=1}^{n} \partial_{12 i k} \Delta R O P_{i t-k}+\sum_{k=1}^{n} \partial_{13 i k} \Delta O C_{i t-k}+ \\
& \sum_{k=1}^{n} \partial_{14 i k} \Delta R E E R_{i t-k}+\varphi_{1 i} E C T_{1 i t-1}+\mu_{1 i t} \\
& \Delta R O P_{i t}=\propto_{2 j}+\sum_{k=1}^{n} \partial_{21 i k} \Delta y_{i t-k}+\sum_{k=1}^{n} \partial_{22 i k} \Delta R O P_{i t-k}+\sum_{k=1}^{n} \partial_{23 i k} \Delta O C_{i t-k}+ \\
& \sum_{k=1}^{n} \partial_{24 i k} \Delta R E E R_{i t-k}+\varphi_{2 i} E C T_{2 i t-1}+\mu_{2 i t} \\
& \Delta O C_{i t}=\propto_{3 j}+\sum_{k=1}^{n} \partial_{31 i k} \Delta y_{i t-k}+\sum_{k=1}^{n} \partial_{32 i k} \Delta R O P_{i t-k}+\sum_{k=1}^{n} \partial_{33 i k} \Delta O C_{i t-k}+ \\
& \sum_{k=1}^{n} \partial_{34 i k} \Delta R E E R_{i t-k}+\varphi_{3 i} E C T_{3 i t-1}+\mu_{3 i t} \\
& \Delta R E E R_{i t}=\propto_{4 j}+\sum_{k=1}^{n} \partial_{41 i k} \Delta y_{i t-k}+\sum_{k=1}^{n} \partial_{42 i k} \Delta R O P_{i t-k}+\sum_{k=1}^{n} \partial_{43 i k} \Delta O C_{i t-k}+ \\
& \sum_{k=1}^{n} \partial_{44 i k} \Delta R E E R_{i t-k}+\varphi_{4 i} E C T_{4 i t-1}+\mu_{4 i t}
\end{aligned}
$$


$E C T_{i t}$ are the error correction terms (ECTs). The long-run causality is measured by the significance of the $t$ statistics of the ECTs. The short-run Granger causality is tested by using F-statistics.

The regression analysis will be conducted in three steps. In the first step, the unit root test which is aimed at testing the order of cointegration is carried out. If the variables are integrated at $\mathrm{I}(0)$ or $\mathrm{I}(1)$, a cointegration test is conducted as the second step. Once the variables are found to be cointegrated, the ECM term will be included in the causality model leading to an ECM based Granger-causality test. The F-statistics captures the shortrun causality and the ECM captures the long-run causality.

\subsection{Data source}

This study examined and analysed the causal relationship between real oil price and economic growth from 1990 to 2018 for a panel dataset of seven low-income and seven middle-income oil-importing countries in SSA. This study used the World Bank (2018) classification of economies to categorise the countries into LICs and MICs. The LICs include Ethiopia, Gambia, Mali, Mozambique, Senegal, Tanzania and Uganda. The MICs include Botswana, Kenya, Mauritania, Mauritius, Namibia, South Africa and Zambia. Annual data were employed in this study and were sourced from the World Development Indicator (WDI, 2019), the US Energy Information Administration (EIA) and the BP Statistical Report, 2019.

Table 1 Data Description

\begin{tabular}{cll}
\hline Variable & Definition & Source \\
\hline $\mathrm{y}$ & $\begin{array}{l}\text { The real GDP per capita at constant 2010 national prices } \\
\text { (in millions 2010 US\$) }\end{array}$ & $\begin{array}{l}\text { World Development Indicators } \\
\text { (WDI) }\end{array}$ \\
ROP & $\begin{array}{l}\text { The real oil price is the spot price of crude oil, per barrel, } \\
\text { sold on the international market which is adjusted for } \\
\text { inflation (in US\$) }\end{array}$ & BP Statistical Review \\
OC & $\begin{array}{l}\text { Oil consumption is the quantity of oil consumed. It is } \\
\text { measured in thousands of barrels per day (mb/d) }\end{array}$ & $\begin{array}{l}\text { US Energy Information } \\
\text { Administration (EIA) } \\
\text { REER }\end{array}$ \\
$\begin{array}{l}\text { The real effective exchange rate is defined as the nominal } \\
\text { exchange rate adjusted by the respective consumer price } \\
\text { index of the trading partners. }\end{array}$ & Brataset \\
\hline
\end{tabular}

\section{RESULTS AND DISCUSSION}

\subsection{Panel unit root tests}

The estimation begins with the unit root test to determine the order of integration of the variables. To test the stationarity of the variables, five-panel unit root tests are employed. The tests are divided into the homogenous unit root process and the heterogeneous unit root process. The Levin, Lin \& Chu t* (LLC) and Breitung t-stat are classified as the homogeneous unit root process, while the Im, Pesaran and Chin (2003), ADF-Fisher Chisquare and the PP-Fisher Chi-square tests assume the heterogeneous unit root process. 
Table 2 Panel Unit root tests

\begin{tabular}{|c|c|c|c|c|c|c|c|}
\hline & Method & & At le & & At first di & ference & Order of \\
\hline & & Interc & ept & Trend & Intercept & Trend & \\
\hline $\mathrm{y}$ & LLC & 0.32 & $(0.626)$ & $1.36 \quad(0.913)$ & $-7.24^{* * * * *}(0.000)$ & $-6.80^{* * * *}(0.000)$ & $\mathrm{I}(1)$ \\
\hline & Breitung & & - & $1.08 \quad(0.859)$ & 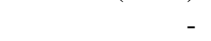 & $-3.45^{* * * *}(0.000)$ & \\
\hline & IPS & 5.00 & $(1.000)$ & $-1.05 \quad(0.147)$ & $-8.91^{* * * *}(0.000)$ & $-7.23^{* * * *}(0.000)$ & \\
\hline & ADF-Fisher & 6.31 & $(1.000)$ & $39.37^{*}(0.075)$ & $133.19^{* * * * *}(0.000)$ & $106.48^{* * * *}(0.000)$ & \\
\hline & PP-Fisher & 6.34 & $(1.000)$ & $48.74^{* * * *}(0.009)$ & $210.57^{* * * *}(0.000)$ & $426.75^{* * * *}(0.000)$ & \\
\hline ROP & LLC & $-4.98^{* * * *}$ & $(0.000)$ & $-1.77^{* *}(0.039)$ & - & $-8.60^{* * * *}(0.000)$ & $\mathrm{I}(1)$ \\
\hline & Breitung & & - & $-0.85 \quad(0.199)$ & - & $-6.09^{* * * *}(0.000)$ & \\
\hline & IPS & $-3.61^{\text {**** }}$ & $(0.000)$ & $-1.59^{* * *}(0.056)$ & - & $-8.13^{* * * *}(0.000)$ & \\
\hline & ADF-Fisher & $61.18^{* * * *}$ & $(0.000)$ & $36.19 \quad(0.138)$ & - & $110.94^{* * * *}(0.000)$ & \\
\hline & PP-Fisher & $61.30^{* * * *}$ & $(0.000)$ & $32.23 \quad(0.265)$ & - & $109.34^{* * * *}(0.000)$ & \\
\hline $\mathrm{OC}$ & LLC & 0.51 & $(0.695)$ & $-2.39^{* * * *}(0.008)$ & $-8.67^{* * * * *}(0.000)$ & - & $\mathrm{I}(1)$ \\
\hline & Breitung & & - & $-2.19^{* * *}(0.014)$ & - & - & \\
\hline & IPS & 3.80 & $(1.000)$ & $-3.01^{* * * *}(0.001)$ & $-11.14^{* * * *}(0.000)$ & - & \\
\hline & ADF-Fisher & 11.79 & $(0.997)$ & $55.28^{* * * *}(0.002)$ & $167.54^{* * * *}(0.000)$ & - & \\
\hline & PP-Fisher & 29.51 & $(0.387)$ & $61.70^{* * * * *}(0.000)$ & $285.02^{* * * *}(0.000)$ & - & \\
\hline REER & LLC & 0.19 & $(0.574)$ & $-1.44^{*}(0.075)$ & $11.85^{* * * *}(0.000)$ & - & $\mathrm{I}(1)$ \\
\hline & Breitung & & - & $-3.32^{* * * *}(0.000)$ & - & - & \\
\hline & IPS & $-1.48^{*}$ & $(0.070)$ & $-2.51^{* * * *}(0.006)$ & $-12.55^{* * *}(0.000)$ & - & \\
\hline & ADF-Fisher & $39.94^{*}$ & $(0.067)$ & $46.64^{* * *}(0.015)$ & $195.54^{* * * *}(0.000)$ & - & \\
\hline & PP-Fisher & 34.31 & $(0.191)$ & $(0.545)$ & $250.62^{* * * *}(0.000)$ & $589.47^{* * * *}(0.000)$ & \\
\hline
\end{tabular}

For all probability values, ${ }^{*},{ }^{* *}$ and ${ }^{* * * *}$ denote significance at $10 \%, 5 \%$ and $1 \%$ level of significance, respectively.

\subsection{Panel Cointegration Test}

Before establishing the direction of causality between the variables, the panel cointegration test is performed to confirm the existence of a cointegrating relationship among the variables of interest. Tables 3 and 4 present the results of the panel cointegration test for the entire dataset, and the panel of LICs and MICs.

The results in Table 3 show that there is a cointegrating relationship among the variables used in this study. These variables are real GDP per capita, real oil price, oil consumption and real effective exchange rate. In the entire dataset, four statistics out of seven reject the null hypothesis of no cointegration. For the country groups, five statistics reject the null hypothesis of no cointegration in the panel of LICs, while four statistics reject the null hypothesis in the panel of MICs.

The presence of a cointegrating relationship is further buttressed by the results of the Kao cointegration test reported in Table 4, which reject the null hypothesis of no cointegration for all the datasets used in this study at the $5 \%$ level of significance. 
The Dynamic Causal Relationship between Oil Price and Economic Growth in Oil-Importing SSA ... 223

Table 3 Results of Pedroni Cointegration test

\begin{tabular}{|c|c|c|c|c|}
\hline \multicolumn{5}{|c|}{ Entire dataset } \\
\hline Test & Statistic & Prob. & Weighted Statistic & Prob. \\
\hline & \multicolumn{4}{|c|}{ Within-dimension } \\
\hline Panel v-Statistic & $9.370^{* * *}$ & 0.000 & $4.943^{* * *}$ & 0.000 \\
\hline Panel rho-Statistic & 0.274 & 0.608 & 1.749 & 0.960 \\
\hline Panel PP-Statistic & $-3.660^{* * * *}$ & 0.000 & -0.717 & 0.237 \\
\hline \multirow[t]{2}{*}{ Panel ADF-Statistic } & $-4.275^{* * * *}$ & 0.000 & $-1.684^{* *}$ & 0.046 \\
\hline & \multicolumn{4}{|c|}{ Between-dimension } \\
\hline Group rho-Statistic & \multicolumn{3}{|c|}{2.808} & 0.998 \\
\hline Group PP-Statistic & \multicolumn{3}{|c|}{-0.551} & 0.291 \\
\hline Group ADF-Statistic & \multicolumn{3}{|c|}{$-2.763^{* * *}$} & 0.003 \\
\hline \multicolumn{5}{|c|}{ LIC } \\
\hline & Statistic & Prob. & Weighted Statistic & Prob. \\
\hline & \multicolumn{4}{|c|}{ Within-dimension } \\
\hline Panel v-Statistic & $7.195^{* * *}$ & 0.000 & $3.568^{* * * *}$ & 0.000 \\
\hline Panel rho-Statistic & -0.572 & 0.284 & 0.949 & 0.829 \\
\hline Panel PP-Statistic & $-4.129^{* * * *}$ & 0.000 & -1.052 & 0.146 \\
\hline \multirow[t]{2}{*}{ Panel ADF-Statistic } & $-4.769^{* * * *}$ & 0.000 & $-2.308^{* *}$ & 0.011 \\
\hline & \multicolumn{4}{|c|}{ Between-dimension } \\
\hline Group rho-Statistic & \multicolumn{3}{|c|}{1.902} & 0.971 \\
\hline Group PP-Statistic & \multicolumn{3}{|c|}{-0.378} & 0.353 \\
\hline Group ADF-Statistic & \multicolumn{3}{|c|}{$-2.024^{* *}$} & 0.022 \\
\hline & \multicolumn{3}{|c|}{ MIC } & \\
\hline & Statistic & Prob. & Weighted Statistic & Prob. \\
\hline & \multicolumn{4}{|c|}{ Within-dimension } \\
\hline Panel v-Statistic & -1.603 & 0.946 & -1.727 & 0.958 \\
\hline Panel rho-Statistic & -0.284 & 0.388 & -0.324 & 0.373 \\
\hline Panel PP-Statistic & $-1.552^{*}$ & 0.060 & $-1.575^{* *}$ & 0.058 \\
\hline \multirow[t]{2}{*}{ Panel ADF-Statistic } & $-1.810^{* *}$ & 0.035 & $-1.776^{* *}$ & 0.038 \\
\hline & \multicolumn{4}{|c|}{ Between-dimension } \\
\hline Group rho-Statistic & & 0.270 & & 0.607 \\
\hline Group PP-Statistic & & $-2.346^{* *}$ & & 0.010 \\
\hline Group ADF-Statistic & & $-2.980^{* * * *}$ & & 0.001 \\
\hline
\end{tabular}

Table 4 Results of Kao Cointegration test

\begin{tabular}{llll}
\hline Statistics & Prob & & Cointegration Status \\
\hline$-2.243^{* *}$ & \multicolumn{3}{l}{ Entire dataset } \\
\hline$-1.952^{* *}$ & 0.013 & & Cointegrated \\
\hline$-2.243^{* *}$ & 0.025 & LIC & Cointegrated \\
\hline
\end{tabular}

For all probability values, $* * *$ and $* * *$ denote significance

at $10 \%, 5 \%$ and $1 \%$ level of significance, respectively. 


\subsection{ECM-Based Causality Model}

This study analyses the causality between oil price and economic growth for the entire dataset and compares the causality in the two country groups, namely LICs and MICs. The cointegrating regressions indicate the presence of causality at least in one direction. However, they do not indicate the direction of causal relationships between the variables (see Granger, 1988; Narayan and Smith, 2008; Odhiambo, 2009; Saidi et al., 2017). The direction of the long-run causal relationship can be observed from the error-correction model (ECM) obtained from the long-run cointegrating vectors (Apergis and Payne, 2010; Saidi and Mbarek, 2016; Saidi et al., 2017). The long-run causal relationship is, therefore, observed through the significance of the t-statistics of the error correction terms (ECTs) in the cointegrating equation (Asongu et al., 2016). The statistical significance of the Fstatistics, on the other hand, determines the short-run causal relationship between the variables used in the model (see Saidi and Mbarek, 2016; Apergis and Payne, 2010). The acceptance or rejection of the null hypothesis for the causal relationships is confirmed at $1 \%, 5 \%$ and $10 \%$ significance levels. Table 5 presents the causal relationship between oil price and economic growth for the entire dataset.

Table 5 Results of Panel Granger causality for the entire dataset

\begin{tabular}{|c|c|c|c|c|c|}
\hline \multirow{3}{*}{$\begin{array}{l}\text { Dependent } \\
\text { Variables }\end{array}$} & \multicolumn{5}{|c|}{ Sources of causality (independent variables) } \\
\hline & \multicolumn{4}{|c|}{ Short-run } & \multirow{2}{*}{$\frac{\text { Long-run }}{\text { ECT }}$} \\
\hline & $\Delta \mathrm{y}$ & $\Delta \mathrm{ROP}$ & $\Delta \mathrm{OC}$ & $\triangle$ REER & \\
\hline \multirow[t]{2}{*}{$\Delta \mathrm{y}$} & - & $4.648^{* *}$ & $10.261^{* * *}$ & $24.906^{* * * *}$ & $-0.001^{\text {*** }}$ \\
\hline & & $(0.032)$ & $(0.002)$ & $(0.000)$ & {$[-4.583]$} \\
\hline \multirow[t]{2}{*}{$\Delta \mathrm{ROP}$} & $3.622^{* *}$ & - & $4.126^{* *}$ & $25.544^{* * * *}$ & $-0.119^{* * * *}$ \\
\hline & $(0.058)$ & & $(0.043)$ & $(0.000)$ & {$[-7.374]$} \\
\hline \multirow[t]{2}{*}{$\Delta \mathrm{OC}$} & $12.052^{* * *}$ & $7.887^{* * *}$ & - & 0.126 & $-0.001^{* * *}$ \\
\hline & $(0.001)$ & $(0.005)$ & & $(0.723)$ & {$[-3.298]$} \\
\hline \multirow[t]{2}{*}{$\triangle \mathrm{REER}$} & $11.018^{* * *}$ & $9.594^{* * *}$ & $5.766^{* *}$ & - & $-0.067^{* * *}$ \\
\hline & $(0.001)$ & $(0.002)$ & $(0.017)$ & & {$[-4.495]$} \\
\hline
\end{tabular}

For all probability values, ${ }^{*},{ }^{* *}$ and ${ }^{* * *}$ denote levels of significance at $10 \%, 5 \%$ and $1 \%$, respectively.

The results reported in Table 5 show that there is evidence of a short-run causality running from real oil price to real GDP per capita and from real GDP per capita to real oil price for the entire dataset. The results are supported by the corresponding F-statistics in the real GDP and oil price equations, which are statistically significant. This finding, therefore, supports a short-run bidirectional causality between oil price and economic growth. Similarly, the long-run results show that there is a bidirectional causality between oil price and economic growth for the entire dataset. This is confirmed by the coefficients of the ECTs in the real GDP and oil price equations, which are negative and statistically significant. The results of the causality test between oil price and real GDP for LICs and MICs datasets are reported in Table 6.

The results reported in Table 6 show that for the LICs, there is a bidirectional causal relationship between real oil price and real GDP in the short run, but a unidirectional causality running from economic growth to real oil price in the long run. A short-run bidirectional is confirmed by the corresponding F-statistics in the real GDP and oil price equations, which have been found to be statistically significant. A long-run unidirectional 
Table 6 Comparison of the Panel Granger causality for the panel of LICs and MICs

\begin{tabular}{|c|c|c|c|c|c|c|c|c|c|c|}
\hline \multirow{4}{*}{$\begin{array}{l}\text { Dependent } \\
\text { Variables }\end{array}$} & \multicolumn{5}{|c|}{ LIC } & \multicolumn{5}{|c|}{$\mathrm{MIC}$} \\
\hline & \multicolumn{5}{|c|}{ Sources of causality (independent variables) } & \multicolumn{5}{|c|}{ Sources of causality (independent variables) } \\
\hline & \multicolumn{4}{|c|}{ Short-run } & \multirow{2}{*}{$\begin{array}{c}\text { Long-run } \\
\text { ECT }\end{array}$} & \multicolumn{4}{|c|}{ Short-run } & Long-run \\
\hline & $\Delta \mathrm{y}$ & $\Delta \mathrm{ROP}$ & $\Delta \mathrm{OC}$ & $\triangle \mathrm{REER}$ & & $\Delta \mathrm{y}$ & $\Delta \mathrm{ROP}$ & $\Delta \mathrm{OC}$ & $\triangle \mathrm{REER}$ & ECT \\
\hline \multirow[t]{2}{*}{$\overline{\Delta y}$} & - & $7.919^{* * * *}$ & 1.808 & $4.167^{* * *}$ & -0.039 & - & $3.379^{*}$ & $5.413^{* *}$ & $14.452^{* * * k}$ & $-0.151^{\text {**** }}$ \\
\hline & & $(0.006)$ & $(0.181)$ & $(0.043)$ & {$[-1.488]$} & & $(0.069)$ & $(0.022)$ & $(0.000)$ & {$[-3.195]$} \\
\hline \multirow[t]{2}{*}{$\Delta \mathrm{ROP}$} & $7.984^{* * * *}$ & - & $3.396^{*}$ & $22.671^{\text {**** }}$ & $-0.056^{* * * *}$ & $4.524^{* *}$ & - & 1.022 & $12.521^{* * * *}$ & $-0.055^{* * *}$ \\
\hline & $(0.005)$ & & $(0.067)$ & $(0.000)$ & {$[-3.233]$} & $(0.035)$ & & $(0.314)$ & (0.001) & {$[-3.211]$} \\
\hline \multirow[t]{2}{*}{$\Delta \mathrm{OC}$} & $2.046^{* *}$ & $10.693^{\text {*** }}$ & - & 2.538 & $-0.175^{* *}$ & $15.433^{* * * *}$ & 0.010 & - & $17.608^{* * *}$ & $-0.004^{* * * *}$ \\
\hline & $(0.043)$ & $(0.001)$ & & (0.113) & {$[-2.607]$} & $(0.000)$ & $(0.920)$ & & $(0.000)$ & {$[-2.868]$} \\
\hline \multirow[t]{2}{*}{$\triangle$ REER } & $4.136^{* *}$ & 2.561 & $3.429^{*}$ & - & $-0.035^{* * * *}$ & 0.322 & 2.107 & $6.352^{* *}$ & - & $-0.042^{* * * *}$ \\
\hline & $(0.044)$ & $(0.112)$ & $(0.066)$ & & {$[-3.736]$} & $(0.572)$ & $(0.149)$ & $(0.013)$ & & {$[-3.311]$} \\
\hline
\end{tabular}

For all probability values, ${ }^{*},{ }^{* *}$ and ${ }^{* * *}$, denote significance at $10 \%, 5 \%$ and $1 \%$

levels of significance, respectively.

causality running from economic growth to real oil price is confirmed by the coefficient of the ECT in the oil price equation, which is negative and statistically significant. For the MICs, the results show that there is a bidirectional causality between oil price and real GDP in the short run and the long run. The short-run result is confirmed by the corresponding Fstatistics in the real GDP and oil price equations, which have been found to be statistically significant. The long-run result, on the other hand, is confirmed by the corresponding coefficients of the ECT in the real GDP and oil price equations, which have been found to be negative and statistically significant.

Table 7 Summary of causality tests

\begin{tabular}{lll}
\hline Panels & Causality & General conclusion \\
\hline LIC (in the short run) & $\begin{array}{l}\text { There is a bidirectional causality } \\
\text { between real oil price and economic growth } \\
\text { LIC (in the long run) }\end{array}$ & $\begin{array}{l}\text { There is a unidirectional causality } \\
\text { from economic growth to real oil price }\end{array}$ \\
MIC (in the short run) & $\begin{array}{l}\text { There is a bidirectional causality } \\
\text { between real oil price and economic growth }\end{array}$ & y ROP \\
MIC (in the long run) & $\begin{array}{l}\text { There is a bidirectional causality } \\
\text { between real oil price and economic growth }\end{array}$ & y $\leftrightarrow$ ROP \\
\hline $\begin{array}{r}\text { Note: y } \leftrightarrow \text { ROP represents a bidirectional causality; y } \rightarrow \text { ROP } \\
\text { represents a unidirectional causality from economic growth to real oil price }\end{array}$
\end{tabular}

\section{CONCLUSION}

In this study, the causal relationship between oil price and economic growth has been examined in 14 oil-importing sub-Saharan African (SSA) countries during the period 1990-2018. Although the causal relationship between oil price and economic growth has been examined in a number of studies, very few studies have been conducted in Africa in general and in SSA in particular. Moreover, the majority of studies conducted suffer from methodological weaknesses. As an example, some studies used bivariate Granger-causality, 
yet studies have shown that bivariate causality suffers from omission bias. Moreover, the majority of the previous studies lumped low-income and middle-income countries together; however, studies have shown that the relationship between oil price and economic growth could be dependent on the level of income of the countries. These findings have important policy recommendations. For the low-income countries, energy conservation policies are necessary in the long run to ensure that energy is used efficiently as a result of the increase in economic growth. Middle-income countries should pay attention to the efficient use of energy while pursuing economic trajectories. In particular, they may consider regulatory policies aimed at normalising oil prices, especially in the long run. Unlike some of the previous studies, this study uses a multivariate Granger-causality model, which incorporates oil consumption and real exchange rate as intermittent variables between oil price and economic growth. The study employed panel cointegration and the panel Granger-causality tests to examine this linkage. In addition, the study countries were divided into two groups, namely LICs and MICs in order to test whether the causality between oil price and economic growth depends on the countries' income levels.

The results from this study show that the causality between oil price and economic growth depends on the countries' income levels. Specifically, the results show that for the LICs, a bidirectional causality between oil price and real GDP tends to prevail in the short run, while a unidirectional causality running from economic growth to real oil price predominates in the long run. However, for MICs, the results show that there is a bidirectional causality between oil price and real GDP in the short run and the long run. Other results show that in LICs, there is: i) a bidirectional causality between real exchange rate and economic growth, and between oil consumption and oil price; ii) a unidirectional causality from real exchange rate to oil price; iii) a unidirectional causality from economic growth to oil consumption. These results apply irrespective of whether the causality is estimated in the short run or the long run. The results for MICs, on the other hand, show that there is: i) a bidirectional causality between oil consumption and economic growth, and between oil consumption and exchange rate; and ii) a unidirectional causality from real exchange rate to oil price and economic growth. Overall, the study found a feedback relationship between oil price and economic growth to predominate in the countries under study.

These findings have important policy recommendations. For the low-income countries, energy conservation policies are necessary in the long run to ensure that energy is used efficiently as a result of the increase in economic growth. Middle-income countries should pay attention to the efficient use of energy while pursuing economic trajectories. In particular, they may consider regulatory policies aimed at normalizing oil prices, especially in the long run.

\section{REFERENCES}

Aliyu, S. U. (2011). Oil price shocks and the macroeconomy of Nigeria: a non-linear approach. Journal for International Business and Entrepreneurship Development, 5(3), 179-198. https://doi.org/10.1504/JIBED.2011.038029

Apergis, N., \& Payne, J. E. (2010). Renewable energy consumption and economic growth: evidence from a panel of OECD countries. Energy Policy, 38(1), 656-660. https://doi.org/10.1016/j.enpol.2009.09.002

Asongu, S., El Montasser, G., \& Toumi, H. (2016). Testing the relationships between energy consumption, CO2 emissions, and economic growth in 24 African countries: a panel ARDL approach. Environmental Science and Pollution Research, 23(7), 6563-6573. https://doi.org/10.1007/s11356-015-5883-7

Baumeister, C. \& Kilian, L. (2016a). Understanding the Decline in the Price of Oil since June 2014. Journal of the Association of Environmental and Resource Economists, 3(1), 131-158. https://doi.org/10.1086/684160 
Baumeister, C., \& Kilian, L. (2016b). Forty Years of Oil Price Fluctuations: Why the Price of Oil May Still Surprise Us. Journal of Economic Perspectives, 30(1), 139-160. https://doi.org/10.1257/jep.30.1.139

Baumeister, C., \& Peersman, G. (2013). Time-varying effects of oil supply shocks on the US economy. American Economic Journal: Macroeconomics, 5(4), 1-28. https://doi.org/10.1257/mac.5.4.1

Behmiri, N. B., \& Manso, J. R. P. (2013). How crude oil consumption impacts on economic growth of SubSaharan Africa?. Energy, 54, 74-83. https://doi.org/10.1016/j.energy.2013.02.052

British Petroleum (2018). Statistical Review of World Energy, $67^{\text {th }}$ Edition.

Cuñado, J., \& de Gracia, F. P. (2003). Do oil price shocks matter? Evidence for some European countries. Energy Economics, 25(2), 137-154. https://doi.org/10.1016/S0140-9883(02)00099-3

Cunado, J., \& De Gracia, F. P. (2005). Oil prices, economic activity and inflation: evidence for some Asian countries. The Quarterly Review of Economics and Finance, 45(1), 65-83. https://doi.org/10.1016/j.qref.2004.02.003

Delgado, N. A. B., Delgado, E. B., \& Saucedo, E. (2018). The relationship between oil prices, the stock market and the exchange rate: Evidence from Mexico. The North American Journal of Economics and Finance, 45, 266-275. https://doi.org/10.1016/j.najef.2018.03.006

Du, L., \& Wei, C. (2010). The relationship between Oil Price Shocks and China's Macroeconomy: An Empirical Analysis. Energy Policy, 38, 4142-4151. https://doi.org/10.1016/j.enpol.2010.03.042

Dumitrescu, E.I., \& Hurlin, C. (2012). Testing for Granger non-causality in heterogeneous panels. Economic Modelling, 29(4), 1450-1460. https://doi.org/10.1016/j.econmod.2012.02.014

Ebohon, O.J. (1996). Energy, economic growth and causality in developing countries: a case study of Tanzania and Nigeria. Energy Policy, 24(5), 447-453. https://doi.org/10.1016/0301-4215(96)00027-4

EIA (2020). Short-Term Energy Outlook, September. Retrieved from: https://www.eia.gov/outlooks/steo/realprices/ \#: :text=Real\%20Petroleum\%20Prices\%20are\%20computed,in\%20some $\% 20 \% 22$ base $\% 22 \% 20$ period

Engle, R.F., \& Granger, C.W. (1987). Co-integration and error correction: representation, estimation, and testing. Econometrica: Journal of the Econometric Society, 251-276. https://doi.org/10.2307/1913236

Granger, C. W. J. (2004). Time series analysis, cointegration, and applications. American Economic Review, 94(3), 421-425. https://doi.org/10.1257/0002828041464669

Granger, C.W. (1988). Some recent development in a concept of causality. Journal of Econometrics, 39(1-2), 199-211. https://doi.org/10.1016/0304-4076(88)90045-0

Hooker, M. A. (1996a). What Happened to the Oil Price Macroeconomics Relationship?. Journal of Monetary Economics, 38, 195-213. https://doi.org/10.1016/S0304-3932(96)01281-0

Hooker, M. A. (1996b). This is What Happened in the Oil Price Macroeconomics Relationship: Reply. Journal of Monetary Economics, 38, 221-222. https://doi.org/10.1016/S0304-3932(96)01283-4

Im, K.S., Pesaran, M.H., \& Shin, Y. (2003). Testing for unit roots in heterogeneous panels. Journal of Econometrics, 115(1), 53-74. https://doi.org/10.1016/S0304-4076(03)00092-7

Jayaraman, T. K., \& Choong, C. K. (2009). Growth and oil price: A study of causal relationships in small Pacific Island countries. Energy Policy, 37(6), 2182-2189. https://doi.org/10.1016/j.enpol.2009.01.025

Jiménez-Rodríguez*, R., \& Sánchez, M. (2005). Oil price shocks and real GDP growth: empirical evidence for some OECD countries. Applied economics, 37(2), 201-228. https://doi.org/10.1080/0003684042000281561

Kilian, L., \& Murphy, D. P. (2014). The role of inventories and speculative trading in the global market for crude oil. Journal of Applied Econometrics, 29(3), 454-478. https://doi.org/10.1002/jae.2322

Kumar, S. (2009). The Macroeconomic Effects of Oil Price Shocks: Empirical Evidence for India. Economics Bulletin, 29(1), 15-37.

Lescaroux, F., \& Mignon, V. (2008). On the influence of oil prices on economic activity and other macroeconomic and financial variables. OPEC Energy Review, 32(4), 343-380. https://doi.org/10.1111/j.1753-0237.2009.00157.x

Levin, A., Lin, C. F., \& Chu, C. S. J. (2002). Unit root tests in panel data: asymptotic and finite-sample properties. Journal of econometrics, 108(1), 1-24. https://doi.org/10.1016/S0304-4076(01)00098-7

Narayan, P. K., \& Smyth, R. (2008). Energy consumption and real GDP in G7 countries: new evidence from panel cointegration with structural breaks. Energy Economics, 30(5), 2331-2341. https://doi.org/10.1016/j.eneco.2007. 10.006

Narayan, P. K., Narayan, S., \& Prasad, A. (2008). Understanding the oil price-exchange rate nexus for the Fiji islands. Energy Economics, 30(5), 2686-2696. https://doi.org/10.1016/j.eneco.2008.03.003

Odhiambo, N. M. (2009). Energy consumption and economic growth nexus in Tanzania: An ARDL bounds testing approach. Energy Policy, 37(2), 617-622. https://doi.org/10.1016/j.enpol.2008.09.077

Odhiambo, N. M., \& Nyasha, S. (2019). Oil price and economic growth in Kenya: A trivariate simulation. International Journal of Sustainable Energy Planning and Management, 19, 3-12. https://doi.org/10.5278/ijsepm.2019.19.2

OECD/IEA (2014). African Energy Outlook. A Focus on Energy Prospects in Sub-Saharan Africa. World Energy Outlook Special Report. 
Rafiq, S., Salim, R., \& Bloch, H. (2009). Impact of crude oil price volatility on economic activities: An empirical investigation in the Thai economy. Resources Policy, 34(3), 121-132. https://doi.org/10.1016/j.resourpol.2008. 09.001

Romer, D. (2018). Advanced macroeconomics. Mcgraw-hill.

Saidi, K., \& Mbarek, M. B. (2016). Nuclear energy, renewable energy, CO2 emissions, and economic growth for nine developed countries: Evidence from panel Granger causality tests. Progress in Nuclear Energy, 88, 364374. https://doi.org/10.1016/j.pnucene.2016.01.018

Saidi, K., Rahman, M. M., \& Amamri, M. (2017). The causal nexus between economic growth and energy consumption: New evidence from global panel of 53 countries. Sustainable cities and society, 33, 45-56. https://doi.org/10.1016/j.scs.2017.05.013

Sarwar, S., Chen, W., \& Waheed, R. (2017). Electricity consumption, oil price and economic growth: Global perspective. Renewable and Sustainable Energy Reviews, 76, 9-18. https://doi.org/10.1016/j.rser.2017.03.063

World Bank (2019). World Development Indicators.

\section{DINAMIČKA UZROČNA VEZA IZMEĐU CENE NAFTE I EKONOMSKOG RAZVOJA U PODSAHARSKIM ZEMLJAMA UVOZNICAMA NAFTE: MULTIVARIJANTNI MODEL}

Ovaj rad istražuje uzročnu vezu između cene nafte i ekonomskog razvoja u 14 zemalja-uvoznica nafte u PodsaharskojAafrici u preiodu od 1990 do 2018. Zemlje se dalje dele u dve grupe, naime sedam zemalja sa niskim prihodima (LIC) i sedan zemalja sa srednjim prihodima (MIC) kako bi se testiralo da li uzročnost između cene nafte i ekonomskog razvoja zavisi od nivoa prihoda zemlje. Za razliku od prethodnih istraživanja koja koriste bivarijantni model, ova studija koristi multivarijantni Grendžerov model uzročnosti, koji uključuje potrošnju nafte i realni devizni kurs kao naizmenične promenljive u bivarijantnom okruženju između cene nafte i ekonomskog razvoja. Studija koristi panel kointegracijske i panel Grendžer-uzročne testove da bi ispitala ovu vezu. Rezultati studije pokazuju da kratkoročno postoji dvosmerna uzročnost uzmeđu cene nafte i ekonomskog razvoja za čitav skup podataka, za LIC i MIC podjednako. Međutim, dugoročno, postoji dvosmerna uzročna veza između cene nafte i ekonomskog razvoja za ceo skup podataka i MIC, ali jednosmerna uzročnost od ekonomskog razvoja do cene nafte za LIC. Sveukupno, studija je utvrdila da je povratni odnos između cene nafte i ekonomskog razvoja dominantan.

Ključne reči: cena nafte, ekonomski razvoj, panel analiza, Grendžer uzročnost, zemlje sa niskim prihodima, zemlje sa srednjim prihodima 